\title{
Will Brazil Follow the Japanese Educational Reforms and Cut the Funding for Research in Humanities? Possibilities and Psycho- political Implications
}

\author{
André Dias \\ Researcher, Regional University of Blumenau \\ Brazil \\ Email and10.dias [AT] gmail.com
}

\begin{abstract}
On May 2019 Brazilian Federal government declared it would follow the Japanese academic model, cutting funding for undergraduate and graduate-level programs and research on Humanities and Social Sciences. The cited reforms were implemented by Japanese Education Minister Shimomura in 2015, but Japan would later back down on these cuts. In Brazil, however, the cuts affect 30\% of the budget for Federal educational institutions and frozen the continuity of the most important program from the Coordination for the Improvement of Higher Education Personnel (CAPES), which distributed grants for researchers on graduate programs. This paper conducts a literature and bibliographic review in order to debate the Brazilian's cuts on Higher Education. It is concluded that those cuts are mainly politically motivated, affecting mostly the hard sciences instead of Humanities and Social Sciences. It is also concluded the political motivations behind the slashing of funding for Education may backfire, fostering the actual and new forms of political associativism between Brazilian students and researchers.
\end{abstract}

Keywords - Higher Education; Educational Public Policies; Politics; Funding.

\section{INTRODUCTION}

On early May 2019, Brazilian government declared a 30\% funding cut to 3 of the most important federal universities: The University of Brasilia, the Federal Fluminense University and the Federal University of Bahia. Later on in the same day, the government announces that this measure would immediately apply to every Brazilian federal educational institution [1]. This measure affects nearly 300 hundred educational institutes and many of them protested against this measure, claiming the cuts will make it impossible for these institutions to keep running. One week later, Bolsonaro administration's blocked the funds for graduate grants. The Coordination for the Improvement of Higher Education Personnel (CAPES) announced that recently approved students will have no funding. The remaining grants will be allocated to graduate programs who are directly contributing to industrial development [2].

Education Minister Abraham Weintraub first said that he had to cut the budget of the federal universities because of their poor performances and ideological stance. According to him, the universities probably have a surplus of money to make shambles and organize ridiculous events [1]. Nihil novi sub sole: Jair Bolsonaro was elected president claiming that most teachers are in fact Marxists agents trained to indoctrinate children. According to him, the Brazilian Higher Education system was kidnapped by Communists [3]; undergraduate and graduate degrees are irrelevant [4]; and that nobody likes a critical young person [5].

But in April, Bolsonaro said that the Ministry of Education was planning to slash funding on Humanities, especially Philosophy and Sociology. The money should be redirected to other programs and research areas, such as Medicine, Veterinary and Engineering. Prior to the cuts, the spending with Humanities was around 2\% of the budget for Higher Education. Weintraub cited Japan as a model of development, saying that even in a richer country like Japan if you want to study Humanities you're not prohibited - but you'll need to fund your studies. In this sense, public money should be spent with more practical research in order to benefit society as a whole [6].

Historically, the Japanese educational system explicitly excluded humanities as a priority. In 1995, on its Basic Law on Science and Technology [7], the Japanese government stated that public policies should focus on applied research, rather than human sciences. Twenty years later, Education Minister Hakuban Shimomura sent a letter to the 86 Japanese federal universities demanding active steps towards the extinction of the Humanities and Social Science courses and departments. At the time, 26 institutions promptly said that they would either reduce or abolish the offer of these courses immediately. According to Shimomura, these measures would allow the government to invest in areas that better meet Japan's needs [8]. 
This paper aims to debate the comparison between the Japanese Education Minister Shimomura politics to enforce the dawn of light sciences and Brazilian Education Minister Weintraub to slash the budget for Higher Education, especially on Humanities. This debate takes in consideration some of the possible outcomes of these cuts in Brazil, especially some of the psycho-political results such as the political consciousness of the population about educational matters and possibilities for new forms of students' activism. For such task, a literature review was conducted in order to provide enough data to analyze both Japanese and Brazilian scenarios. Some news published on journals were also used to illustrate the facts, mostly because the debated events are still very recent and there aren't many published academic papers about this subject.

\section{THE JAPANESE MODEL: ARE THERE SCIENCES WITHOUT HUMANITIES?}

Japan is internationally known for its scientific and economic development, and their plans for education are ambitious: in 10 years, Japan wants at least 10 of its universities in the top 100 world universities rankings [9]. It is assumed that Japan achieved this stage by getting to a point of universal access to Higher Education. According to the Japanese Ministry of Education, Culture, Sports, Science and Technology (MEXT) [10], when we consider universities, specialized schools, junior and technological colleges the percentage of 18-year-old Japanese enrolled are over $70 \%$. In 2011, there were over 3,2 million students enrolled in 1224 universities and colleges in Japan: 385 thousand of these students were studying Humanities and 879 thousand were studying Social Sciences. Most of these students were enrolled at private institutions of Higher Education.

Under the Abe administration, Japan took many measures to improve GDP growth to fight a financial crisis and to expand its political influence internationally with actions like the creation of the Cool Japan Fund [11], devoted to promoting Japanese lifestyle around the globe in order to expand the demand for Japanese goods. These are part of the Japan Revitalization Strategy, a set of very straightforward measures usually known as Abenomics. In the educational field, these measures are related to the internationalization of the Higher Education linked with industrial needs [9].

It must be remembered that the government spending in Higher Education is declining since 2000 [12], especially after the economic stagnation in the 90's, known as Japan's lost decade [13]. Hence 1995 Japan stated on its Basic Law on Science and Technology [7] that it would focus the Higher Education funding on hard sciences. When the crisis has come, humanities departments suffered, and the situation was aggravated by the cuts on the funding of humanities and social sciences planned by Education Minister Hakuban Shimomura [8]. Many attributed the action to the right-wing views of the Abe administration, saying that the government was following a path to dismantle intellectual political resistance. Japan would later drawback on the Humanities and Social Sciences cuts under the argument that these disciplines should be blended with practical and theoretical aspects of technological development, as for example ethics and logical thinking [14].

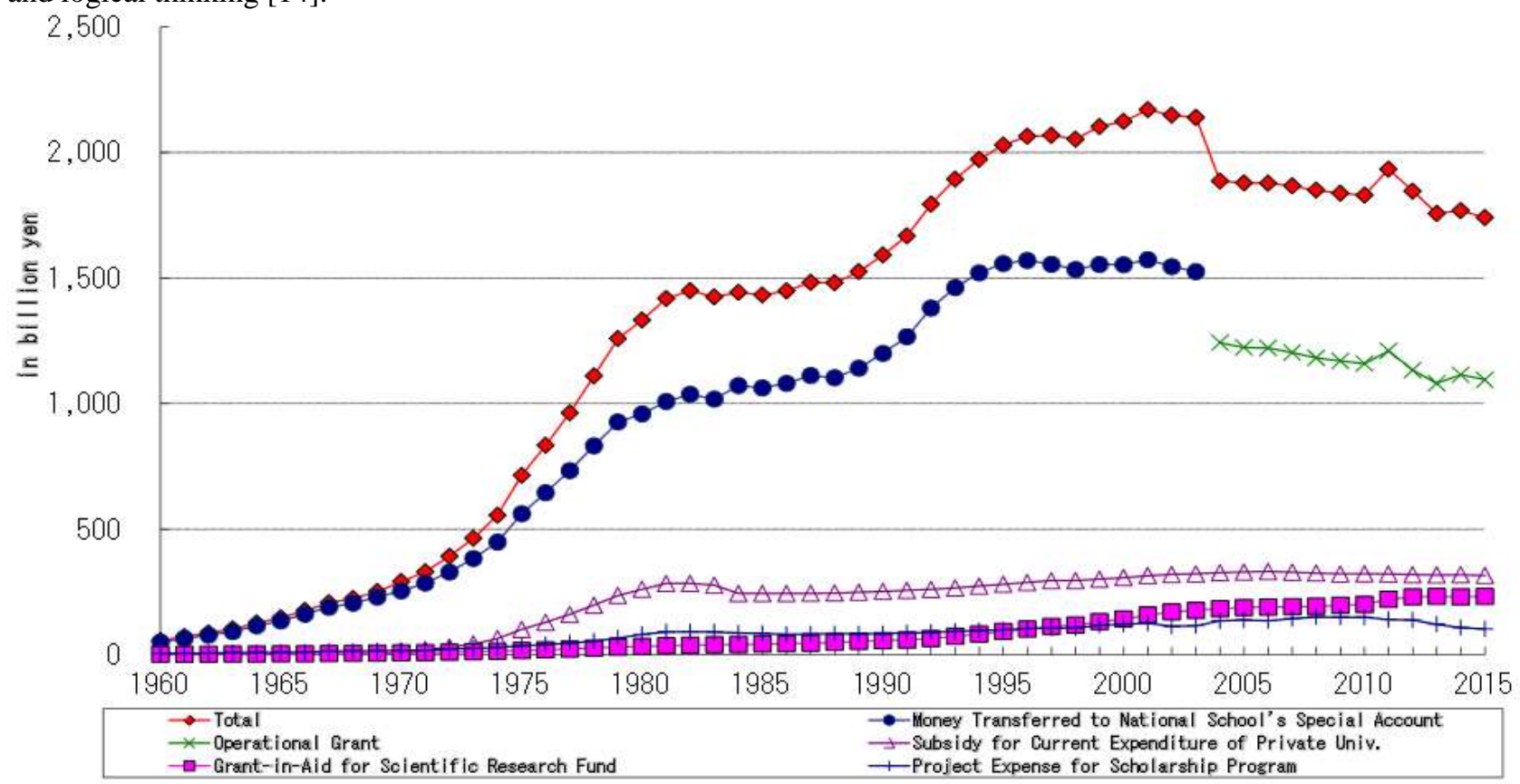

Graphic 1: Japanese government spending on Higher Education (1960-2015) in billion yen [12] 


\section{THE BRAZILIAN SCENARIO: ARE THERE HUMANITIES WITHOUT SCIENCES?}

As previously mentioned, Brazil recently suffered a huge shift in its educational policies. After two mandates of Fernando Henrique Cardoso (FHC) from 1995 to 2002, the educational scenario in Brazil saw the expansion of private institutions of Higher Education, many of which were from international groups of shareholders and offered low-quality services. The public education was underfunded and suffered many vetoes from the Federal government under FHC's administration. During the following government, the Worker's Party Lula administration's (2003-2010), there was a huge increase in public spending, especially social programs. Lula boosted the growth of both the private and the public education with national programs to fund students to Higher Education, especially the poorest. The public education grew under a program named REUNI, which aimed to expand and decentralize Federal universities and institutes [15].

Lula was followed in the presidency by his Minister of Mines and Energy Dilma Rousseff, a friend from the Worker's Party and the first Brazilian women elected president. Dilma followed Lula's policies on Higher Education, continuing the expansion of the public system of Federal institutions. She was elected in 2011 and reelected in 2015 . In 2013 she passed a law to destinate $75 \%$ of the royalties on the recently found oil fields known as "pré-sal" to education and healthcare [16]. Dilma was removed from office in 2016 after a white coup d'état [17]. She was followed by the vicepresident Michel Temer until 2018. In 2019, the far-right candidate Jair Bolsonaro was elected by a thin margin. The "pré-sal" oil reserves were sold between 2018 and 2019 by Temer and Bolsonaro [18].

Bolsonaro's educational cuts were based on the idea that Humanities and Social Sciences courses are just some kind of leftist political think tanks. His administration continuously claimed that Brazilian education was destroyed by cultural Marxism and so Brazil should follow Japan's model of education and prioritize hard sciences. Problem is: Brazilian spending on Philosophy and Sociology represents only $2 \%$ of the public spending on undergraduate courses, $2,5 \%$ of the graduate programs, and received only 1,4\% of CAPES grants for graduate-level research [19]. Even worse, the generalized cuts are even higher than $30 \%$ in more than half of the Federal universities, affecting mostly the hard sciences labs and basic maintenance budget [20].

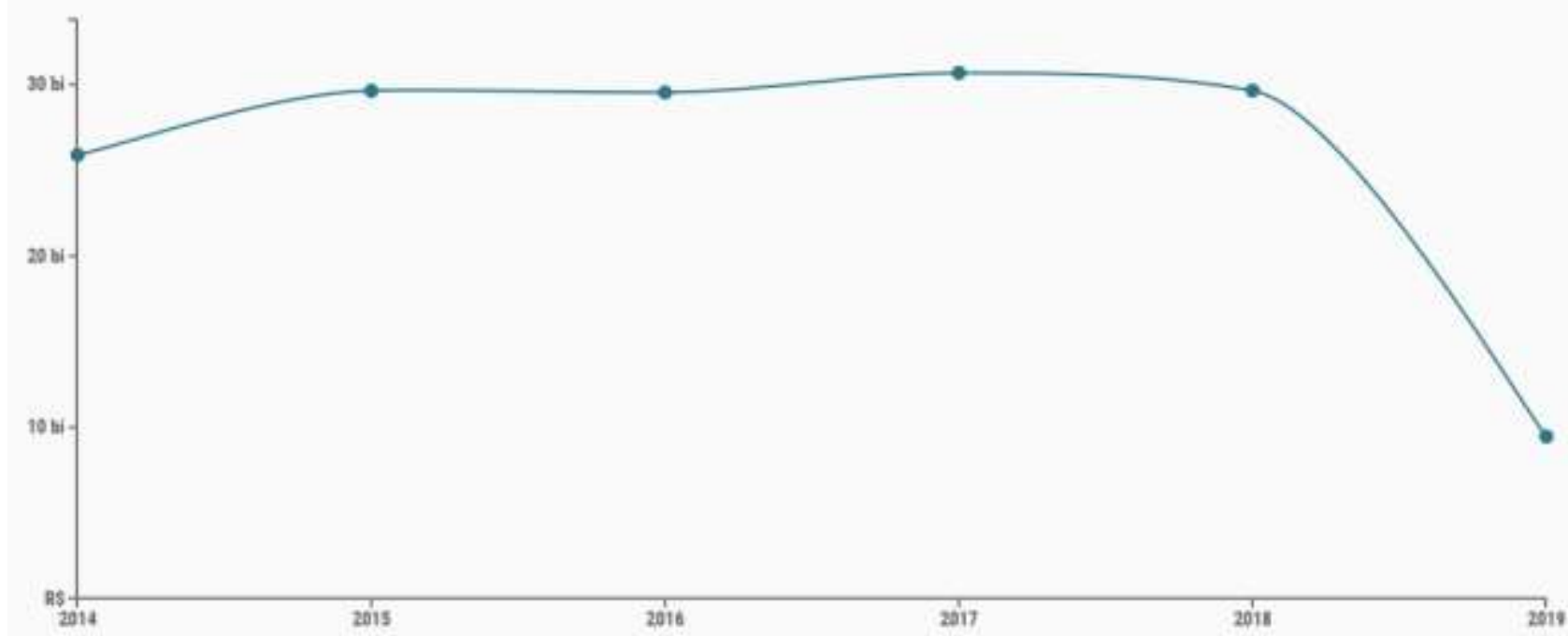

Graphic 2: Brazilian government spending on Higher Education (2014-2019) in billion reais [24]

The measure sparked many manifestations around the country. Protests were held in at least 200 cities against the cuts and many universities and schools struck. Bolsonaro called the protesters "imbeciles" and "useful idiots" [21]. He would later call the protesters "imbeciles" again, stating that the academic autonomy shouldn't be confused with sovereignty [22]. He also imposed a decree taking the autonomy from the Federal universities to elect their deans and high-echelon administrators. The decree foresees the investigation of any previous activity from anyone to fill these and other posts on Federal administration by the Brazilian Intelligence Agency (ABIN) [23].

The government claimed the cuts are a necessary emergency measure in order to contain public spending while facing a huge financial crisis. Blaming the previous administration, the current administration said these cuts will prevent an economic disaster, especially if the Congress rejects the cuts proposed by Bolsonaro to social security. Indeed, Brazil is currently facing a very pessimistic economic scenario: five months after Bolsonaro's victory, its GDP projections are shrinking fast [25]. The opposition claims that these measures against education are not only ideologically influenced, but they are also a way to create political pressure to approve the reforms proposed by the presidency. 


\section{DISCUSSION: POSSIBILITIES AND PSYCHO-POLITICAL IMPLICATIONS}

The slashing of scientific funding during a financial crisis is far from being something new. Both Japan and Brazil, as previously demonstrated, reduced the budget for education and research when facing economic difficulties. The question here isn't the reduction of funding, but the psycho-political implications of these cuts. When we look closer to these policies, they are clearly related to political control of critical thinking, including measures to reduce free speech, the autonomy of educational institutions and to dismantle students' movements and associations.

\subsection{Comparing Brazilian and Japanese Cuts}

The Japanese case is a very particular one, once we found a planned public policy since 1995 to actively reduce the funding for Humanities [7]. Also, one can question the level of autonomy of the Japanese government after World War 2 and how the Abe administration is dealing with the United Statsian interference. Abe's right-wing government could also benefit from the reduction of courses devoted to promoting critical thinking. In this sense, the cuts on Human and Social Sciences could improve political stability and foster the development of new technologies.

When the Brazilian government cited the Japanese model of scientific funding [6], it was giving a clear message about the political use of scientific investment. It is hard to believe that Bolsonaro really thinks the education was taken by Soviet-trained Marxists' teachers [3] but is totally comprehensible that he may perceive the liberal thinking and the educational autonomy as a treat. The budget cut imposed in Brazil will make it impossible for many Federal institutions to survive and the hard sciences will be the most affected with this measure, once they demand more investment in materials and infrastructure.

In this sense, the cuts are nothing like the measures taken by Japan. Besides both governments are aligned with rightwing ideas, Japan focused on hard sciences and research and development of applied technologies. On the other hand, the Brazilian government is cutting the basic discretionary budget of its universities, destroying the public system of Higher Education building during the right-winged Brazilian military regime (1964-1985) [26][27] and expanded during the Worker's Party administration (2002-2016) [15].

\subsection{Psycho-political Implications}

Many political interests are entrenched with these recent measures from Bolsonaro's cabinet, but two could be mentioned as key factors to understand this political crisis. First, there is a process to delegitimize the Higher Education institutions, especially the Federal universities. A huge amount of fake news was delivered in order to create an image of the students and professors as Communists, drugs users, criminals, and depraved people who walked naked on campus [28]. The objective of these fake news is to attack and demoralize the political active intellectual class. Such tactics were widely used during Bolsonaro's campaign to the presidency [29][30]. Many initiatives were created in some universities to detect fake news, such as the research programs developed at the Minas Gerais Federal University [31] and by a partnership between the University of São Paulo and São Carlos Federal University [32].

Secondly, there is a huge political effort to reduce and, if possible, to extinct the mechanisms created by the Federal Constitution of 1988 to improve the social conditions of the population. These mechanisms were implemented in order to provide social protection as public policies of social security, social assistance, free universal healthcare, and unemployment insurance [33]. These efforts are often disguised as austerity measures, taken temporally in order to retake the market's confidence. But the real objectives of such measures are to improve production and to cut social spending in order to reduce the amount of taxes paid by the economic elites [34]. Austerity is, in fact, one of the pillars of the neoliberal economic policies [35].

These two interests are the basis of a neoliberal excluding political agenda which is permeated by many authoritarian characteristics. Although Brazil is a democratic country, we must consider that every national State is oligarchic [36]: it has its own elites and these elites are trained and educated differently from the rest of the population, usually attending different educational institutions, independently if the government is democratic or not [37]. The absence of funding for a high-quality public and free educational system open to any citizen is the basis to transform the educational system into a machinery to perpetuate and legitimize a hierarchical subordination to these elites [38]. This legitimization affects the subject on its psychological level [39], making it harder or even impossible for a student from the most deprived layers to access and even to perceive education as a tool for social ascension [38].

Besides the maneuvers to create a bad image of the Federal universities and of its students as rioters among the general population, Brazil may face some huge changes in its students' movements. The country saw some new forms of organization among students in 2016, when almost 1200 schools were occupied by High School students. These students were fighting against the curricular reforms and budget cuts approved by the Federal government at the time. This experience was extremely important to change political awareness among the students about their rights. Some rightwing movements acted against the occupation, mostly the movements funded by the Movimento Brasil Livre, a thinktank backed by the Koch brothers [40]. 
This scenario of frequent disputes on the educational field may foster changes among the political consciousness of tertiary students as well. A new protest was announced by the National Students' Unity (UNE) on May 15. The students are planning to start the protests on May 30 [41]. Historically commanding the fight for students' rights in Brazil, the UNE is directly linked with the academic resistance to the Brazilian dictatorship [42][43]. But the current political configurations may also give birth to new students' associations, or even change the face of the UNE and other political organizations, especially the ones linked to Higher education.

Among the general population, the opinions are still divided. Many still support Bolsonaro's agenda, but things might be changing. On May 26, many rallies happened around the country supporting the government's measures. But it seems that they weren't enough to end the political crisis, mainly because Bolsonaro couldn't mobilize enough people on the streets to do so [44]. The presidential popularity is on free fall while disapproval is growing fast and how surpassed the approval ratings [45], especially after the corruption's investigations conducted against Bolsonaro's son, Flavio Bolsonaro [46].

The Education Minister Weintraub made it clear that these measures of cutting the budget for Education are devoted to putting pressure on Congress to approve the reforms on Social Security as Bolsonaro's cabinet wishes [47]. He was later called by Chamber of Deputies on May 15 to give explanations about the funding cuts; he blamed, among other things, the Worker's Party's administration for the political and financial crisis. Among many commentaries, some defended that the cuts were necessary because the money invested by the government on Federal universities was being used to pay male prostitutes for homosexual professors [48]. Together with the manifest signed by a group of 1400 renowned academics [49], this pressure may undermine these measures on medium and long term [50].

\section{CONCLUSION}

The Brazilian government announced a policy of funding cuts to Federal institutions and to research and development programs, affecting mostly the Higher Education. These cuts are being conducted under the guidance of Education Minister Weintraub, who assumed the ministry after Bolsonaro had his first minister, Ricardo Vélez Rodríguez, fired in April [51]. Besides Weintraub cited Japan as a model to follow in order to cut the funding to Humanities and Social Sciences, these Brazilian policies have nothing to do with the Japanese cuts. Japanese spending on Higher Education was never reduced in the same proportion as Brazil is doing right now. Also, Japan scaled down the cuts on Humanities and Social Sciences, while in Brazil the funding cuts will hit the hard sciences directly, once the funding for Humanities was already diminished.

Many political motives are behind these policies, as for example targeting Education in order to pressure the approval of Bolsonaro's reforms to cut spending on Social Security. Another example is the ideological opposition held by the current presidency against intellectuals and universities. Allegedly, the Federal universities are centers for Marxist indoctrination. But Historically, they were a key factor to generate resistance against the Brazilian military dictatorship, which is highly praised by Bolsonaro and his followers, to the point he mentioned it on $25 \%$ of his discourses when he served as a deputy [52].

This scenario may cause some structural changes to student's movements and organizations around the country, once we can find some new challenges to be faced. The UNE is still the reference to guide many of these changes, but some movements are not involved with the Union and may generate new ways of student's organization. Even the political consciousness of the general population may change: Educational matters could be something valuable and directly related to political affairs. In the last instance, the cuts can be perceived as a call to action and a possibility to organize political resistance to fight for access and the quality of Brazilian Higher Education.

\section{REFERENCES}

[1] Luiza Tenente, Patrícia Figueiredo, "Entenda o Corte de Verbas das Universidades Federais e Saiba Como São os Orçamentos das 10 Maiores”, G1, May 15, 2019.

[2] CAPES, Ofício Circular $n^{\circ}$ 1/2019-GAB/PR/CAPES: Recolhimento de Bolsas Não Utilizadas, Brasília, May 8, 2019.

[3] Talita Fernandes, "Bolsonaro diz que Combate ao Marxismo vai Melhorar Desempenho na Educação, Folha de São Paulo, Dec. 31, 2018.

[4] Ricardo Rigel, "Profissionais Contestam Afirmação de Bolsonaro de que Técnico de Refrigeração Pode Ganhar Mais de R\$ 12 Mil”, Extra, Aug. 30, 2018. 
[5] Lucas Rezende, "Ninguém Quer Saber de Jovem com Senso Crítico, diz Bolsonaro em Vitória”, Folha de São Paulo, Jul. 31, 2018 .

[6] Helena Borges, Bolsonaro Defende Cortes em Cursos de Humanas e diz que Dinheiro do Contribuinte Deve ir para 'Leitura, Escrita e Fazer Conta', O Globo, Apr. 26, 2019.

[7] Japanese Cabinet Office, Law n. 130 of 1995, November 15, 1995 - The Science and Technology Basic Law, 1995.

[8] Jack Grove, "Social Sciences and Humanities Faculties 'to Close' in Japan After Ministerial Intervention", Times Higher Education, Sep. 14, 2015.

[9] Prime Minister Office of Japan, “Japan Revitalization Strategy”, 2014.

[10] MEXT, “Higher Education in Japan”, 2012.

[11] Japanese Cabinet Office, Act n. 51 of Jun. 19, 2013 - Act on Cool Japan Fund, Inc., 2013.

[12] Research Institute for Higher Education at Hiroshima University, "Government Expenditure for Higher Education", Statistics of Higher Education, Hiroshima University, 2019.

[13] Masazumi Wakatabe, "Turning Japanese? Lessons from Japan's Lost Decade to the Current Crisis", Center on Japanese Economy and Business Working Papers at Columbia University, n. 309, 2013.

[14] Helena Borges, "Japão Vai Voltar Atrás em Política Educacional Citada Como Referência por Governo Bolsonaro", O Globo, Apr. 26, 2019.

[15] Vilmar Aguiar, "Um Balanço das Políticas do Governo Lula para a Educação Superior: Continuidade e ruptura", Revista de Sociologia e Política, v. 24, n. 57, p. 113-126, 2016.

[16]República Federativa do Brasil, "Sancionada a Lei que Destina Royalties do Petróleo para Saúde e Educação", Brazilian Government, Sep. 09, 2013

[17] Ivana Jinkings, Kim Doria, Murilo Cleto, Por Que Gritamos Golpe? Para entender o impeachment e a crise política no Brasil, Boitempo, Brazil, 2016.

[18] Daniel Silveira, Alba Valéria Mendonça, "Quatro Áreas de Pré-sal são Leiloadas pelo Governo com Ágio de 170,58\%; Veja Resultados”, G1, Sep. 28, 2018.

[19] Paulo Saldaña, Estêvão Gamba, "Proposta de Cortar Verba de Cursos de Humanas Tem Pouco Peso Prático", Folha de São Paulo, Apr. 27, 2019.

[20] Paulo Saldaña, "Corte é Maior do que 30\% do Orçamento Livre em Mais da Metade das Federais", Folha de São Paulo, May 08, 2019.

[21] G1, "Protestos e Paralisações Contra Cortes na Educação Ocorrem em Todos os Estados e no DF", G1, May 12, 2019.

[22] O Globo, "Bolsonaro Chama Manifestantes pela Educação de 'Pessoalzinho’”, O Globo, May 18, 2019.

[23] Diário Oficial da União, Decreto n. 9.794 de Maio de 2019 - Dispõe sobre os atos de nomeação e de designação para cargos em comissão e funções de confiança de competência originária do Presidente da República e institui o Sistema Integrado de Nomeações e Consultas - Sinc no âmbito da administração pública federal, n. 92, May 15, 2019.

[24] Controladoria-geral da União, "Educação", Portal da Transparência, 2019.

[25] Banco Central do Brasil, "Expectativas de Mercado", Relatório de Mercado Focus, 2019.

[26]Edson Martin, Paulino José Orso, "A Expansão do Ensino Superior no Contexto do Regime Militar: Seus desdobramentos no oeste paranaense”, In Proceeding of the VII Seminário Nacional de Estudos e Pesquisas, 2006. 
[27] Rodrigo Patto Sá Motta, “As Universidades e o Regime Militar”, Zahar, Brazil, 2014.

[28] G1, "É fake que Foto Mostra Estudantes Nus Fazendo Manifestação Dentro de Universidade”, G1, May 20, 2019.

[29] Cristina Tardáguila, Fabrício Benvenuto, Pablo Ortellado, "Fake News is Poisoning Brazilian Politics. WhatsApp Can Stop It", The New York Times, Oct. 17, 2018.

[30] Ed Bracho-Polanco, “How Jair Bolsonaro Used 'Fake News' to Win Power”, The Conversation, Jan. $08,2019$.

[31] Júlia Calasans, “Universidades e Fake News: Estudiosos analisam fenômeno”, Minas Gerais Federal University, May 17, 2019.

[32] Denise Cassati, "Ferramenta para Detectar Fake News é Desenvolvida pela USP e UFSCar", ICMC USP, Oct. 15, 2018.

[33] Guilherme Delgado, Luciana Jaccoud, Roberto Passos Nogueira, "Seguridade Social: Redefinindo o Alcance de Cidadania”, Políticas Sociais: Acompanhamento e Análise, IPEA, Brazil, 2000.

[34] Esther Solano Gallego, “O Ódio Como Política: A reinvenção das direitas no Brasil”, Boitempo, Brazil, 2018.

[35] Nick Anstead, “The Idea of Austerity in British Politics, 2003-2013”, Political Studies, v. 66, n. $2,2017$.

[36] Raymond Aron, Démocratie et Totalitarisme, Gallimard, France, 1965.

[37] Jacques Rancière, La Haine de la Democratie, La Fabrique, France, 2005.

[38] István Mészaros, A Educação Para Além do Capital, Boitempo, Brazil, 2005.

[39] Alessandra dos Santos Oliveira, Ana Mercês Bahia Bock, "Escolha do Curso por Prounistas: Estudando a dimensão subjetiva da desigualdade”, Psicologia Escolar e Educacional, v. 20, n. 2, 2016.

[40] Aldimara Catarina Delabona Brito Boutin, Simone de Fátima Flach, "O Movimento de Ocupação de Escolas Públicas e suas Contribuições para a Emancipação Humana”, Inter-ação, v. 42, n. 2, 2017.

[41] Angela Pinho, "Une Convoca Novo Megaprostesto Contra Cortes na Educação para o dia 30”, Folha de São Paulo, May 15, 2019.

[42] Ann Mische, "De Estudantes a Cidadãos: Redes de jovens e participação política”, Revista Brasileira de Educação, n. $5,1997$.

[43] Ricardo Antunes, Marcelo Ridenti, “Operários e Estudantes Contra a Ditadura: 1968 no Brasil”, Mediações, v. 12, n. 2, 2007.

[44] Mariana Schreiber, "Manifestações Não Foram Grandes o Suficiente para Bolsonaro Vencer Crise, Avaliam Analistas Políticos", BBC NEWS BRASIL, May 26, 2019.

[45] Flavia Marreiro, "Desaprovação do Governo Bolsonaro Supera Aprovação pela Primeira Vez, Mostra Pesquisa do Atlas Político”, El País, May 21, 2019.

[46] Fabio Leite, Marcelo Godoy, “Investigação Sobre Flávio Bolsonaro Alcança 37 Imóveis”, Estadão, May 26, 2019.

[47] Globo News, "Ministro Admite Liberar Verbas para Educação se Reforma da Previdência for Aprovada", May 07, 2019.

[48] Alessandra Azevedo, Maria Eduarda Cardim, Bernardo Bittar, “Ao Vivo: Ministro é Sabatinado por Deputados Sobre Cortes na Educação”, Correio Braziliense, May 15, 2019.

[49] L’Internationale du Genre, “Liste des Signataires Contre le Projet de Jair Bolsonaro de Supprimer les Subventions Publiques Destinées Aux Études de Sociologie et de Philosophie”, Le Monde, May 6, 2019. 
[50] Adriano Machado, “Au Brésil, les Sciences Sociales et les Humanités ne Sont Pás un Luxe”, Le Monde, May 06, 2019.

[51] Deliz Ortiz, Guilherme Mazui, “Uma Semana Após Ser Demitido, Vézes Rodríguez se Encontra com Bolsonaro: 'Vim me despedir”", G1, Apr. 15, 2019.

[52] Rodrigo Menegat, "Bolsonaro Mencionou a Ditadura em 1/4 dos seus Discursos como Deputado", Estadão, Mar. 30, 2019. 